\title{
PENGARUH MEETING PAGI DAN SORE TERHADAP TINGKAT EFEKTIFITAS PEKERJA PADA PROYEK TRANS PARK BINTARO
}

\author{
Siti Abadiyah, M.T ${ }^{1}$ dan Karyo, S.T ${ }^{2}$ \\ ${ }^{1,2}$ Program Studi Teknik Sipil Universitas Muhammadiyah Tangerang, Jln Perintis Kemerdekaan I/33 \\ Cikokol Kota Tangerang \\ Email ${ }^{1}$ :abadi_dede01@yahoo.com \\ Email ${ }^{2}$ : bhajank1994@gmail.com
}

\begin{abstract}
ABSTRAK
Penelitian ini berjudul "Pengaruh Meeting Pagi Dan Sore Terhadap Tingkat Efektivitas Pekerja Pada Proyek Trans Park Bintaro". Adapun penelitian ini bertujuan untuk mengidentifikasi seberapa pengaruhnya Meeting Pagi Dan Sore Terhadap Tingkat Efektivitas Pekerja. Penelitian ini dilakukan di PT. Adhi Persada Gedung atau lebih spesifiknya di jalan Rasuna Said, Bintaro Sektor 9, Tangerang Selatan, Banten. Pengambilan sampel dalam penelitian ini digunakan sebanyak 40 responden, teknik pengumpulan datanya adalah dengan melalui kuesioner yang dibagikan kepada responden, dan adapun variabel penelitian adalah Meeting Pagi (X1), Meeting Sore (X2), Efektivitas Pekerja (Y). Penelitian ini menggunakan analisis deskriptif dengan pendekatan kuantitatif, dan untuk menguji tingkat reliabilitasnya dengan menggunakan Cronbach Alpha dan kemudian data diolah dengan Analisis Regresi Linier Berganda. Pengujian Hipotesis menggunakan Uji F dan Uji t dengan taraf signifikansi 10\%. Peneliti menggunakan alat bantu SPSS Versi 25. Dari hasil analisi regresi linier berganda menunjukkan bahwa Efektivitas Pekerja dipengaruhi oleh variabel Meeting Pagi dan variabel Meeting Sore. Hasil determinasi (R2) menggunakan nilai adjusted r square, karena menggunakan regresi dengan lebih satu variabel terikat, yaitu sebesar 0,657, yang artinya variabel Meeting Pagi dan variabel Meeting Sore kerja mempengaruhi Efektivitas Pekerja sebesar $65,7 \%$ sementara sisanya $34,3 \%$ dipengaruhi oleh variabel lain yang tidak diteliti. Pada perhitungan uji $\mathrm{F}$ dan uji t dapat dilihat bahwa variabel Meeting Pagi dan variabel Meeting Sore secara bersama-sama berpengaruh terhadap Efektivitas Pekerja. Dengan begitu Meeting Sore (X2) mempengaruhi Efektivitas Pekerja sebesar 0,149 artinya, jika variabel Meeting Sore (X2) mengalami peningkatan sebesar 0,149 maka, Efektivitas Pekerja akan meningkat secara linier sebesar 0,620. Sebaliknya jika variabel Meeting Sore (X2) mengalami penurunan maka, Efektivitas Pekerja akan menurun pula.
\end{abstract}

Keyword: Efektivitas Pekerja, Meeting Pagi dan Meeting Sore

\section{PENDAHULUAN}

Dalam pelaksanaan kegiatan pembangunan di Indonesia secara umum dalam hal melindungi pekerja terutama mengenai Keselamatan dan Kesehatan Kerja (K3) masih sering terabaikan terutama pada pelaksanaan pembangunan bidang pekerjaan umum dengan konstruksi bangunan sederhana, hal ini ditunjukkan dengan masih tingginya angka kecelakaan kerja pada penyelenggaraan konstruksi, tenaga kerja di sektor jasa konstruksi mencakup sekitar 7-8\% dari jumlah tenaga kerja diseluruh sektor, dan menyumbang $6.45 \%$ dari PDB di Indonesia. Sektor jasa konstruksi adalah salah satu sektor yang paling berisiko terhadap kecelakaan kerja, disamping sektor utama lainnya yaitu pertanian, perikanan, perkayuan, dan pertambangan. Jumlah tenaga kerja di sektor konstruksi yang mencapai sekitar 4.5 juta orang, 53\% diantaranya hanya mengenyam pendidikan sampai dengan tingkat Sekolah Dasar, bahkan 
sekitar $1.5 \%$ dari tenaga kerja ini belum pernah mendapatkan pendidikan formal apapun (Iman Kurniawan Wicaksono dan Moses L. Singgih, 2011).

Data BPJS Ketenagakerjaan jumlah kecelakaan dan korban meninggal dunia sejak lima tahun terakhir (2014-2018). Terlihat bahwa pada tahun 2014 terjadi kecelakaan sebanyak 105.383 kali dengan korban meninggal dunia sebanyak 2.375 jiwa. Pada tahun 2015, terjadi kecelakaan sebanyak 110.285 kali dengan korban meninggal dunia sebanyak 2.308 jiwa. Pada tahun 2016, terjadi kecelakaan sebanyak 101.367 dengan korban meninggal dunia sebanyak 2.382 jiwa. Pada tahun 2017, terjadi kecelakaan sebanyak 123.000 kali dengan korban meninggal dunia sebanyak 3.000 jiwa. Pada 2018 sejak Januari hingga Maret telah terjadi kecelakaan sebanyak 5318 kali dengan korban meninggal dunia sebanyak 87 jiwa. Berdasarkan data tersebut didapat banyak faktor penyebab terjadi kecelakaan kerja salah satunya ialah budaya pekerja dan kurang disiplinnya para tenaga kerja didalam mematuhi ketentuan mengenai K3. Pembentukan budaya kerja dan tingkat disiplin pekerja harus selalu diingatkan dan dicontohkan oleh perusahaan atau organisasi yang menyelengarakan. Meeting pagi dan sore digunakan pada Proyek Trans Park Bintaro guna pengingatan dan pencontohan budaya kerja dan disiplin dalam K3 pada pekerja. Berdasarkan pandangan tersebut dirumuskan masalah yaitu, seberapa besar Pengaruh Meeting Pagi Dan Sore Terhadap Tingkat Efektivitas Pekerja Pada Proyek Trans Park Bintaro?

\section{Penelitian Terdahulu}

Multazam HT, pada penelitiannya tahun 2015 tentang Pengaruh Kesehatan Dan Keselamatan Kerja Terhadap Kinerja Karyawan, (Studi Kasus: PT. Semen Tonasa di Kabupaten Pangkep). Menggunakan metode penelitian analisis deskriptif dengan pendekatan kuantitatif, dan untuk menguji tingkat reliabilitasnya dengan menggunakan Cronbach Alpha dan kemudian data diolah dengan Analisis Regresi Linier Berganda. Hasil penelitian ini berdasarkan pada nilai Adjusted R Squarea pada hasil SPSS yang didapat nilai sebesar 0,685 . Artinya variabel kesehatan dan keselamatan kerja memberikan pengaruh terhadap kinerja karyawan sebesar 68,5\%. Dengan demikian, kesehatan dan keselamatan kerja berpengaruh secara simultan terhadap kinerja karyawan pada PT. Semen Tonasa di Kabupaten Pangkep.

Dwi Handoko pada penelitiannya ditahun 2014 dengan judul Analisa Pengaruh Keselamatan Dan Kesehatan Kerja (K3) Pada Pekerja Bangunangedung Penataan Ruang Kementerian Pekerjaan Umum. Menggunakan metode penelitian metode kuantitatif dengan pengujian hipotesis, dianalisis menggunakan regresi linear berganda dengan metode Ordinary Least Square (OLS) menggunakan bantuan program statistik SPSS. Berdasarkan pengujiannya penulis membagi 6 sub bagian penilaian pada Kesehatan dan keselamatan kerja yaitu pada peraturan, prosedur, peralatan, pengarahan, menetapkan sasaran, dan memantau pelaksanaan. 6 sub bidang tersebut secara bersamasama berpengaruh terhadap kesadaran keselamatan dan kesehatan kerja (K3) pada pekerja bangunan gedung Penataan Ruang Kementerian Pekerjaan Umum. Hal ini ditunjukkan oleh uji $\mathrm{F}$ yang didapat nilai $\mathrm{F}$ hitung> F tabel $(65,092>2,198)$, sehingga Ho ditolak.

\section{Kesehatan dan Keselamatan Kerja}

Keselamatan dan kesehatan kerja difilosofikan sebagai suatu pemikiran dan upaya untuk menjamin keutuhan dan kesempurnaan baik jasmani maupun rohani tenaga kerja pada khususnya dan manusia pada umumnya, hasil karya dan budayanya menuju masyarakat makmur dan sejahtera. Sedangkan pengertian secara keilmuan adalah suatu ilmu pengetahuan dan penerapannya dalam usaha mencegah kemungkinan terjadinya kecelakaan dan penyakit akibat kerja.

Bentuk kecelakaan tidak terjadi begitu saja, kecelakaan terjadi karena tindakan yang salah atau kondisi yang tidak aman. Kelalaian sebagai sebab kecelakaan merupakan nilai tersendiri dari teknik keselamatan. Ada pepatah yang mengungkapkan tindakan yang lalai seperti kegagalan dalam melihat atau berjalan mencapai suatu yang jauh diatas sebuah tangga. Hal tersebut menunjukkan cara yang lebih baik selamat untuk menghilangkan kondisi kelalaian dan memperbaiki kesadaran mengenai keselamatan setiap karyawan.

Studi kasus menunjukkan hanya proporsi yang kecil dari pekerja sebuah industri terdapat kecelakaan yang cukup banyak. Pekerja pada industri mengatakan itu sebagai kecenderungan kecelakaan. Untuk mengukur kecenderungan kecelakaan harus menggunakan data dari situasi yang menunjukkan tingkat resiko yang ekivalen 


\section{Meeting Pagi}

Meeting pagi adalah kegiatan pengarahan tentang $\mathrm{K} 3$ yang ditujukan kepada seluruh pekerja. Meeting pagi dihadiri oleh Kepala regu pekerja, Mandor, Para Pengawas dan Manager dari internal maupun dari subkontraktor. Safety morning harus dilakukan oleh setiap proyek selama 10-15 menit. Pelaksanaan safety morning minimal 2 minggu sekali. Semakin banyak resiko, frekuensi meeting pagi semakin meningkat. Meeting pagi biasa dilakukan sebelum pekerjaan dimulai atau saat masuk jam kerja.

\section{Meeting Sore}

Meeting sore adalah untuk mengevaluasi kerja dan pencapaian target yang telah dilakukan pada hari itu. Dalam acara safety meeting setiap subkontraktor, pemborong, atau mandor menugaskan secara khusus personil yang bertugas untuk memastikan bahwa setiap pekerjaan yang di laksanakan dalam keadaan sudah diminimalisir berbagai kecelakaan kerja yang mungkin terjadi. Dalam Meeting sore hal yang penting untuk disampaikan adalah mengenai evaluasi dari hari hari sebelumnya. Evaluasi dan informasi sangat diperlukan agar seluruh karyawan mengetahui permasalahan apa saja yang dihadapi oleh perusahaan dan isu isu yang beredar saat ini.

\section{Efektivitas}

Efektivitas adalah suatu kondisi yang menunjukkan tingkat keberhasilan atau pencapaian suatu tujuan yang diukur dengan kualitas, kuantitas, dan waktu, sesuai dengan apa yang telah direncanakan sebelumnya Beberapa juga menjelaskan arti efektivitas adalah tingkat keberhasilan yang dihasilkan oleh seseorang atau organisasi dengan cara tertentu sesuai dengan tujuan yang ingin dicapai. Dengan kata lain, semakin banyak rencana yang berhasil dicapai maka suatu kegiatan dianggap lebih efektif.

Menurut Kamus Besar Bahasa Indonesia (KBBI), efektivitas adalah kegunaan, aktivitas, dan kesesuaian dalam suatu kegiatan antara seseorang yang melakukan tugas dan tujuan yang ingin dicapai.Suatu kegiatan atau kegiatan dapat dikatakan efektif jika memenuhi kriteria tertentu. Efektivitas berkaitan erat dengan pelaksanaan semua tugas utama, pencapaian tujuan, ketepatan waktu, dan adanya upaya aktif atau partisipasi dari pelaksana tugas.

\section{METODE PENELITIAN}

\section{Objek penelitian}

Penulis melakukan penelitian dengan mengambil objek penelitian pada Proyek Trans Park Bintaro. Adapun penelitian ini dilakukan untuk mengetahui Pengaruh meeting pagi dan sore terhadap tingkat efektifitas pekerja pada PT. Adhi Persada Gedung di Proyek Trans Park Bintaro.

\section{Jenis Penelitian}

Penelitian ini menggunakan analisis deskriptif dengan pendekatan kuantitatif dan menggunakan teknik analisis regresi berganda dibantu dengan program SPSS. Metode kuantitatif yaitu suatu metode yang menggunakan sistem pengambilan sampel dari suatu populasi dan menggunakan kuesioner terstruktur sebagai alat pengumpulan data. Pendekatan kuantitatif digunakan untuk mencari informasi faktual secara mendetail dan mengidentifikasi masalah-masalah atau untuk mendapatkan justifikasi keadaan dan kegiatan-kegiatan yang sedang berjalan. Pendekatan tersebut digunakan untuk mengetahui pengaruh kesehatan dan keselamatan kerja terhadap kinerja karyawan.

\section{Data Primer}

Data primer adalah data yang diperoleh langsung dari lapangan. Data primer pada penelitian ini adalah data yang dikumpulkan secara langsung berupa hasil kuisioner responden mengenai pengaruh keselamatan dan kesehatan kerja (K3) terhadap kinerja pekerja pada Proyek Trans Park Bintaro .

\section{Data Sekunder}

Data sekunder adalah data atau sumber yang didapat dari bahan bacaan. Penelitian ini data sekunder diperoleh dari perusahaan yang dapat dilihat dokumentasi perusahaan, buku-buku referensi, dan informasi lain yang berhubungan dengan penelitian.

\section{Populasi}

Populasi adalah wilayah generalisasi yang terdiri dari objek atau subjek yang mempunyai kualitas dan karakteristik tertentu. Berdasarkan definisi populasi maka yang menjadi populasi dari penelitian ini adalah seluruh karyawan PT. Adhi Persada Gedung di Proyek Trans Park Bintaro. 


\section{Sampel}

Sampel adalah bagian dari jumlah dan karakteristik yang dimiliki oleh populasi tersebut. Dan penentuan ukuran sampel pada penelitian ini menggunakan rumus Slovin,

\section{Definisi Operasional Variabel}

Untuk memberikan persamaan persepsi kepada para pembaca, maka peneliti memberikan batasanbatasan terhadap variabel-variabel yang diteliti. Meeting pagi (Safety morning) adalah kegiatan pengarahan tentang K3 yang ditujukan kepada seluruh pekerja. Safety morning dihadiri oleh Kepala regu pekerja, Mandor, Para Pengawas dan Manager dari internal maupun dari subkontraktor., sebagai variabel X1. Meeting sore adalah untuk mengevaluasi kerja dan pencapaian target yang telah dilakukan pada hari itu. Dalam acara safety meeting setiap subkontraktor, pemborong, atau mandor menugaskan secara khusus personil yang bertugas untuk memastikan bahwa setiap pekerjaan yang di laksanakan dalam keadaan sudah diminimalisir berbagai kecelakaan kerja yang mungkin terjadi., sebagai variabel $\mathrm{X} 2$. Efektifitas Pekerja adalah hasil kerja yang dapat dicapai oleh seseorang atau kelompok orang dalam suatu organisasi sesuai dengan wewenang dan tanggung jawab masing-masing dalam rangka upaya mencapai tujuan organisasi bersangkutan secara legal tidak melanggar hukum dan sesuai dengan moral maupun etika, sebagai variabel Y.

\section{Teknik Pengumpulan Data}

Teknik pengambilan data yang digunakan dalam penelitian ini adalah sebagai berikut:

1. Kuesioner

Kuesioner diberikan pada pekerja selama 1 minggu hari kerja karena kuisioner tidak dibagikan bagitu saja, namun dengan cara mewawancarai tiap pekerja yang dijadikan sampel. Kuiseoner diisikan langsung oleh penulis di karnakan situasi kondisi lapangan pekerja konstruksi yang kurang mendukung. Pengambilan data menggunakan kuisioner dilaksanakan pada tanggal 10 sampai 11 Agustus 2020. Kondisi pandemi yang sedaang melanda menjadikan jadwal wawancara kuisioner dilaksanakan hanya pada saat jam istirahat siang.

2. Dokumentasi,

Dilakukan pada saat melaksanakan kerja pratek atau magang. Dokumentasi bukan hanya pada gambar pada saat pelaksanaan meeting pagi dan sore, namun mempelajari lebih dalam kinerja karyawan berdasarkan kondisi proyek, yaitu pada gambar DED, dan struktur organisasi pada papulasi yang diteliti.

\section{Teknik Analisis Data dan Pembahasan}

Dari hasil data yang terkumpul, penulis mencoba untuk mengolah dan menganalisis data tersebut dengan menggunakan analisis kuantitatif. Maksud dari analisis kuantitatif, yaitu analisis yang menginterpretasikan data dalam bentuk angka-angka dan digunakan sebagai alat dalam statistik sehingga memudahkan dalam menaksirkan data mentah yang diperoleh. Analisis ini meliputi:

\section{Uji Validitas}

Uji validasi untuk mengetahui kelayakan butir-butir dalam suatu daftar (konstruk) pertanyaan dalam mendefinisikan suatu variabel. Menilai masing-masing butir pertanyaan dapat dilihat dari nilai corrected item-total correlation.

Suatu butir pertanyaan dikatakan valid jika nilai r-hitung yang merupakan nilai dari corrected item-total correlation > dari r-tabel yang diperoleh melalui Df (Degree of Freedom). Untuk menguji valid tidaknya pertanyaan dapat dilakukan melalui program komputer Excel Statistic Analysis \& SPSS.

\section{Uji Realibilitas}

Reliabilitas merupakan ukuran suatu kestabilan dan konsistensi responden dalam menjawab hal yang berkaitan dengan konstruk-konstruk pertanyaan yang merupakan dimensi suatu variabel dan disusun dalam suatu bentuk kuesioner. 
Alat ukur yang akan digunakan adalah cronbach alpha melalui program komputer Excel Statistic Analysis \& SPSS. Reliabilitas suatu konstruk variabel dikatakan baik jika memiliki nilai cronbach alpha $>0,60$.

\section{Uji Asumsi Klasik}

Uji asumsi klasik diperlukan dalam regresi linier berganda dengan tujuan untuk memperoleh nilai penaksir atau nilai koefisien á dan â yang tidak bisa sehingga menjadi nilai yang terbaik. Untuk mendapatkan Uji asumsi klasik diperlukan beberapa uji diantaranya:

\section{Uji Normalitas}

Sebelum dilakukan pengujian hipotesis dengan regresi linier berganda, akan dilakukan pengujian terlebih dahulu terhadap normalitas data. Pengujian normalitas data dalam penelitian ini akan dilakukan dengan uji Kolmogorov dan Smirnov. Konsep dasar dari uji normalitas Kolmogorov-Smirnov adalah dengan membandingkan distribusi data (yang akan diuji normalitasnya) dengan distribusi normal baku. Distribusi normal baku adalah data yang telah ditransformasikan ke dalam bentuk Z-Score dan diasumsikan normal. Jadi sebenarnya uji Kolmogorov- Smirnov adalah uji beda antara data yang diuji normalitasnya dengan data normal baku. Pengambilan keputusan pada uji Kolmogrov-Smirnov didapatkan dari nilai Sig. uji Kolmogrov-Smirnov, dimana jika nilai sig. lebih besar (>) 0,05 maka distribusi data dinyatakan normal (Wahana Komputer, 2005:54). Sementara itu, perlakuan terhadap data yang normal dapat dilakukan dengan beberapa cara (Wahana Komputer, 2005:52):

1. Jika jumlah sampel besar dapat menghilangkan nilai outliner dari data.

2. Melakukan transformasi data.

3. Menggunakan alat analisis nonparametris.

\section{Uji Multikolieniritas}

Uji Multikolieniritas merupakan situasi adanya korelasi variabel-variabel bebas diantara satu dengan yang lainnya, yang mana hubungan antara variabel bebas tersebut lebih tinggi dari hubungan variabel bebas terhadap variabel terikat (Kuncoro, 2003:98). Cara yang dapat dilakukan untuk mengatasi multikolinearitas antara lain dengan metode Koutsoyiannis, mentransformasikan variabel-variabel dan memperoleh lebih banyak data. Berdasarkan metode ini, langkah awal yang dilakukan adalah regresi variabel terikat atas setiap variabel bebas yang terkandung dalam suatu model regresi yang sedang diuji. Kemudian dari hasil regresi ini, dipilih salah satu model regresi yang secara apriori dan statistik yang paling meyakinkan. Model regresi yang terpilih ini disebut regresi elementer (elementary regression). Selanjutnya dimasukkan satu persatu variabel bebas lainnya untuk diregresikan dalam kaitannya dengan variabel terikat yang telah ditentukan. Hasil regresi yang terjadi diteliti baik mengenai koefisien regresi, standard error yang berkaitan dengan koefisien regresi ini maupun R2. Variabel bebas yang baru dimasukkan kedalam percobaan dapat diklasifikasikan sebagai variabel bebas yang berguna (useful), tidak perlu (superfluous) dan merusak hasil (detrimental). penelitian ini akan digunakan metode VIF (Variance Inflation Factor) untuk mendeteksi ada tidaknya gejala multikolieniritas.

Analisis ini pada dasarnya dimaksudkan untuk mengetahui dan menunjukkan adanya hubungan linier diantara variabel-variabel bebas dalam model regresi. Pengujian Multikolinieritas dalam penelitian ini dilakukan dengan cara dengan cara menghitung VIF (Variance Inflanatory Factor) dan Tol (Tolerance). Jika nilai VIF diatas 10 dan Tol dibawah 0,01 maka berarti terjadi Multikolinearitas (Wahana Komputer, 2005:38). Dan begitu pun sebaliknya jika nilai VIF dibawah 10 dan Tol diatas 0,01 maka berarti tidak terjadi multikolinearitas.

\section{Uji Heteroskedastisitas}

Heteroskedastisitas merupakan kesalahan atau residual dari model yang diamati tidak memiliki variance yang konstan dari satu observasi ke observasi lainnya (Kuncoro, 2003:96). Keadaan heterokedastisitas akan menyebabkan penaksiran koefisien regresi jadi tidak efisien. Hasil taksiran dapat menjadi kurang dari semestinya, melebihi dari semestinya atau menyesatkan. Untuk mengetahui ada atau tidaknya gejala heterokedastisitas adalah melalui uji Gletser. Dalam uji Gletser dilakukan regresi kesalahan penggangu terhadap setiap variabel bebas yang diduga. Dari hasil pengujian tersebut akan diambil 
keputusan, bila angka signifikansi > 0,05 (Alhusin, 2003:223) pada taraf kepercayaan 95\%, maka tidak heteroskedatisitas terjadi.

Analisis Regresi Berganda

Analisis ini digunakan untuk mengetahui apakah ada pengaruh yang positif dari variabel independen $(\mathrm{X} 1$, dan $\mathrm{X} 2$,) terhadap variabel dependen $(\mathrm{Y})$ dengan model regresi sebagai berikut :

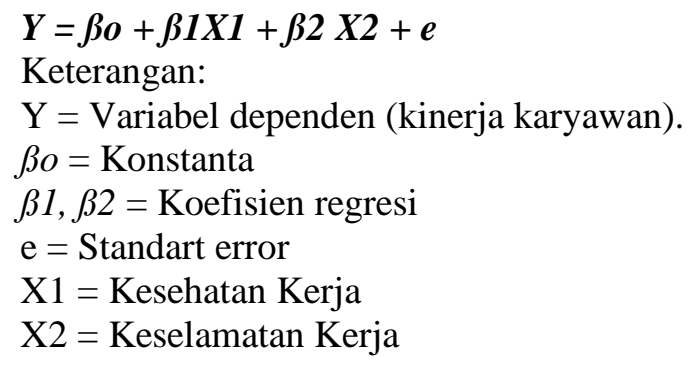

Uji Simultan (Uji F)

Uji F digunakan untuk mengetahui pengaruh secara bersama-sama variabel bebas secara signifikan terhadap variabel terikat. Jika Fhitung > Ftabel maka dapat dikatakan bahwa variabel bebas dapat menerangkan variabel terikatnya secara serentak. Sebaliknya apabila Fhitung < Ftabel maka variabel bebas tidak memiliki pengaruh terhadap variabel terikatnya. Untuk lebih mudahnya dapat dengan melihat probalitasnya dan membandingkannya dengan taraf kesalahan (X1 dan X2) yang digunakan yaitu $10 \%$ atau 0,10 . Jika probalitasnya < taraf kesalahan, maka dapat dikatakan bahwa variabel bebas dapat menerangkan variabel terikatnya secara serentak, begitu pula sebaliknya.

\section{Uji Parsial (Uji T)}

Uji t digunakan untuk mengetahui apakah masing-masing variabel bebasnya secara sendiri-sendiri atau parsial berpengaruh secara signifikan terhadap variabel terikatnya. Apabila thitung $>t$ tabel maka dapat dikatakan signifikan, yaitu terdapat pengaruh antara variabel bebas yang diteliti dengan variabel terikatnya. Sebaliknya jika thiung $<\mathrm{t}$ tabel maka dapat dikatakan tidak signifikan. Untuk mempermudah perhitungan analisis data guna mendapatkan data yang akurat dan meminimalkan kesalahan, pengolahan data dilakukan dengan bantuan Software Statistical Program of Social Science (SPSS) ver. 25 for Windows.

Koefisien Determinasi (R2) bertujuan untuk mengetahui seberapa besar kemampuan variabel independen menjelaskan varabel dependen. Nilai $R$ square dikatakan baik jika diatas 0,5 karena nilai $R$ square berkisar antara $0-1$.

\section{ANALISA DAN PEMBAHASAN}

\section{Analisis}

Analisis data dalam penelitian ini dilakukan terhadap data yang diperoleh melalui penyebaran kuesioner kepada seluruh sampel penelitian, yaitu pada Pekerja Pada Proyek Trans Park Bintaro. Berikut uraian mengenai hasil penelitian dan pembahasannya

\section{Data Responden}

Berdasarkan hasil penelitian yang telah dilaksanakan di PT. Adhi Persada Gedung. Di Bintaro Tangerang Selatan terhadap 40 responden melalui penyebaran kuesioner,

\section{Deskripsi Variabel Penelitian}

Berikut ini akan dijelaskan tentang item-item penelitian yang terdiri dari variabel Meeting pagi (Safety morning) (X1), Meeting sore (X2), dan Efektifitas Pekerja (Y). 


\section{Hasil dan Olah Statistik}

\section{Uji Validitas}

Pengujian tingkat validitas dilakukan terhadap data dari ketiga variabel, yaitu Meeting Pagi, Meeting Sore, dan Efektivitas Pekerja. Pengujian korelasi antara skor item dengan skor total. Suatu item kuisioner dinyatakan valid apabila nilai $r$ hitung $>r$ tabel $(n-2)$. Dalam pengujian ini, koefisien korelasi kritis yang diperoleh dari Tabel distribusi $r$ dengan menggunakan $\mathrm{df}=(\mathrm{n}-2)=40-2=38$. Dengan taraf signifikansi sebesar 5\%, maka diperoleh r-Tabel sebesar 0,361.

\section{Uji Reliabilitas}

Pada penelitian ini, analisis reliabilitas dilakukan terhadap ketiga kuesioner penelitian, yaitu kesadaran, pengawasan, dan kepatuhan pekerja bangunan. Uji reliabilitas ini diukur melalui koefisien alpha (Cronbach) yang diperoleh dengan teknik reliability analysis.

\section{Uji Normalitas}

Uji normalitas pada penelitian ini dilakukan dengan teknik Kolmogorov-Smirnov Test dengan ketentuan data yang dikatakan normal jika signifikansi p (Asymp. Sig.) $>0,05$. Data menunjukkan bahwa hasil uji normalitas dengan Kolmogorov-Smirnov Test nilai signifikansi p (Asymp. Sig.) yang lebih besar dari 0,05, yaitu sebesar 0.2. Nilai signifikansi p (Asymp. Sig.) yang lebih besar dari 0,05 menunjukkan bahwa residual dari estimasi regresi bersifat normal.

\section{Uji Heteroskedastisitas}

Data menunjukkan bahwa semua nilai P-value >0,025. Hal ini menunjukkan bahwa tidak ada variabel bebas dari pengujian yang memiliki pengaruh signifikan terhadap nilai absolut residual. Dengan demikian, dapat disimpulkan bahwa tidak terdapat gejala heteroskedastisitas pada model regresi.

\section{Uji Multikolinearitas}

Data menunjukkan bahwa di antara variabel bebas tersebut tidak ada korelasi atau tidak terjadi multikolinearitas pada model regresi linier. Hal ini dapat diketahui dari nilai toleransi lebih dari 0,1 atau nilai VIF kurang dari 10. Dengan demikian, penelitian ini bebas dari gejala multikolinearitas.

\section{Analisis regresi berganda}

Pengukuran Pengaruh Meeting Pagi Dan Sore Terhadap Tingkat Efektivitas Pekerja dilakukan melalui analisis regresi. Analisis ini merupakan analisis statistik yang digunakan untuk menjawab permasalahan penelitian. Analisis regresi yang dilakukan adalah analisis regresi berganda.

\section{Uji Parsial (Uji t)}

Variabel Meeting Sore (X2) mempengaruhi Efektivitas Pekerja sebesar 0,149 artinya, jika variabel Meeting Sore (X2) mengalami peningkatan sebesar 0,149 maka, Efektivitas Pekerja akan meningkat secara linier sebesar 0,620. Sebaliknya jika variabel Meeting Sore (X2) mengalami penurunan maka, Efektivitas Pekerja akan menurun pula.

\section{Uji Simultan (Uji F)}

Hasil perhitungan statistik uji-F pada data menunjukkan nilai f hitung sebesar 4,635. Setelah itu dibandingkan dengan nilai $\mathrm{F}$ tabel sebesar 3,24 dengan signifikansi $10 \%(0,10)$. Jadi dapat disimpulkan $\mathrm{F}$ hitung $>\mathrm{F}$ tabel $(4,635>3,24)$ dengan Sig F 0,000 < 0,10, ini berarti bahwa variabel independen Meeting Pagi (X1) dan Meeting Sore (X2) secara bersama - sama berpengaruh positif dan signifikan terhadap Efektivitas Pekerja, sehingga dinyatakan bahwa keselamatan dan kesehatan kerja berpengaruh secara simultan terhadap efektivitas Pekerja Pada PT. Adhi Persada Gedung. Artinya, semakin tinggi tingkat Keselamatan dan Kesehatan Kerja karyawan maka semakin tinggi pula tingkat Efektivitas Pekerja. 


\section{KESIMPULAN}

\section{Kesimpulan}

Berdasarkan hasil penelitian uji-F pada data menunjukkan nilai f hitung sebesar 4,635. Setelah itu dibandingkan dengan nilai $\mathrm{F}$ tabel sebesar 3,24 dengan signifikansi $10 \%(0,10)$. Dapat disimpulkan $\mathrm{F}$ hitung > F tabel $(4,635>3,24)$ dengan Sig F $0,000<0,10$, ini menunjukkan variabel independen Meeting Pagi (X1) dan Meeting Sore (X2) secara bersama - sama berpengaruh positif dan signifikan terhadap Efektivitas Pekerja. Variabel Meeting Sore (X2) mempengaruhi Efektivitas Pekerja sebesar 0,149 artinya, jika variabel Meeting Sore (X2) mengalami peningkatan sebesar 0,149 maka, Efektivitas Pekerja akan meningkat secara linier sebesar 0,620. Sebaliknya jika variabel Meeting Sore (X2) mengalami penurunan maka, Efektivitas Pekerja akan menurun pula.

\section{Saran.}

- Berdasarkan hasil penelitian yang telah dipaparkan dapat menjadi point utama dalam penerapan K3 pada proyek Proyek Trans Park Bintaro pada umumnya dan pada PT. Adhi Persada Gedung pada khususnya.

- Setelah peelitian ini diharapkan bagi PT. Adhi Persada Gedung dapat lebih tefokus kembali setiap K3 bukan hanya dalam pengaplikasian meeting pagi dan sorenya, namun pada keseluruhan rangkaian pada pelaksanaan $\mathrm{K} 3$.

- Banyak poin yang dapat dikaji lebih lanjut pada K3 sehingga dapat kembali dilanjutkan pada penelitian selanjutnya.

\section{DAFTAR PUSTAKA}

Multazam HT, 2015, Pengaruh Kesehatan Dan Keselamatan Kerja Terhadap Kinerja Karyawan, (Studi Kasus: PT. Semen Tonasa di Kabupaten Pangkep). Laporan Skripsi UIN Alauddin Makassar.

Handoko Dwi, 2014, Analisis Pengaruh Keselamatan Dan Kesehatan Kerja (K3) Pada Pekerja Bangunan Gedung Penataan Ruang Kementrian Pekerjaan Umum. Jurnal Konstruksia Volume 5 Nomer 2 Agustus 2014.

Al Kautsar, Indria, dkk. 2013. Pengaruh Keselamatan Dan Kesehatan Kerja Terhadap Kinerja Karyawan (Studi pada Karyawan Tetap Bagian Produksi PR. Sejahtera Abadi Malang)”. Jurnal Administrasi Bisnis (JAB), Vol. 6, No. 2, Desember

Andi Wijayanto. 2012. Pengaruh Keselamatan Dan Kesehatan Kerja Terhadap prestasi Kerja Karyawan (Studi pada Karyawan PT. PLN Persero Semarang)". Jurnal Administrasi Bisnis (JAB), Vol. 1, No. 1, September.

Anwar, Rizqy Murody. 2012. Pengaruh Kesehatan Dan Keselamatan Kerja Terhadap Kinerja Karyawan Pada PT. Kusuma Dipa Nugraha Mojokerto. Skripsi. Fakultas Ekonomi Universitas Pembangunan Nasional Veteran Jawa Timur. 